Research Article

\title{
Biochemical Indices of Male Camelus dromedarius during Breeding and Non-Breeding Season under Farming System
}

\author{
Asim Faraz ${ }^{1 *}$, Abdul Waheed ${ }^{1}$, Nasir Ali Tauqir ${ }^{2}$ and Muhammad Shahid Nabeel ${ }^{3}$ \\ ${ }^{1}$ Department of Livestock and Poultry Production, Bahauddin Zakariya University Multan, Pakistan; ${ }^{2}$ Department of \\ Animal Science, University of Sargodha, Pakistan; ${ }^{3}$ Camel Breeding and Research Station Rakh Mahni, Livestock and Dairy \\ Development Department, Punjab, Pakistan.
}

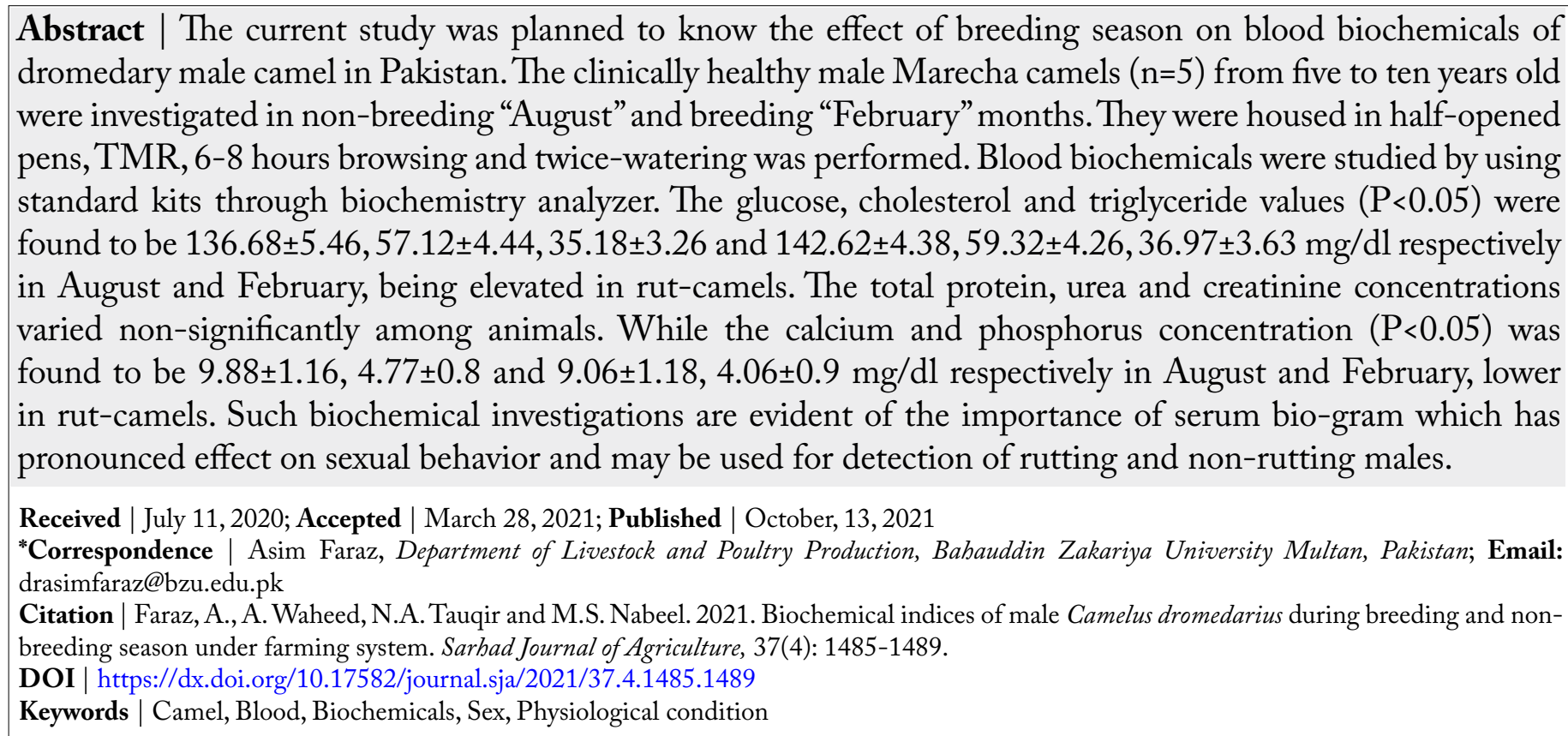

\section{Introduction}

The dromedary camel is vital domestic environment, where the harsh and hostile climatic conditions adversely affect the survival of other livestock species (Faye, 2014; Kadim, 2013; Faraz, 2020, 2021). The camel provides milk and meat in this environment (Osman et al., 2015; Faraz et al., 2019a, b, c).

The camels are found to be seasonal breeders with breeding season in cooler months with endocrinological, behavioral and biochemical change during rut (Yagil and Etzion, 1980; Marai et al.,
2009). The rut in males may go 2-3 months (Tibary and Anouassi, 1997) while remained quiescent for rest year. Regarding serum biochemicals, small changes observed as affected by age, sex and seasonal effects. So, these could be used as indirect tool to assess the rutting condition in the males.

The blood constituents as health mirrors (Momenah, 2014) could provide valuable information regarding general health and physiological condition of animals (Aichouni et al., 2013). Mostly the camel research is survey based in Pakistan (Faraz et al., 2021), so the previous studies not justify requirements of the subject. Current study covers biochemical parameters in reference to breeding season about Marecha camel 
reared under farming system in Thal desert, will add the primary database of camel science.

\section{Materials and Methods}

The trial was attained at CBRS which is located in desert Thal. A number of 5 healthy Marecha males were sampled.Animals were dewormed and vaccinated by injection Ivermectin and Trypamedium-Samorine, respectively. The concentrate $(4-5 \mathrm{~kg})$ of DM-90.32, CP-18.06, NDF-29.09, ADF-14.41, TDN-70 and $\mathrm{ME}-2.41 \mathrm{Mcal} / \mathrm{kg}$ DM was fed with Cicer arientinum $(5 \mathrm{~kg})$ as TMR in manger beside 6-8 hours browsing. Water was offered twice a day; salt lumps and 90110 grams minerals-mixture was also offered on daily basis.

Blood samples were drained by jugular puncture for biochemical analysis by using standard kits in DL-9000-Italy biochemistry analyzer. The digested sample was used for determination of calcium and phosphorus in atomic absorption spectrophotometer at High Tech Lab, University of AgricultureFaisalabad (Faraz et al., 2018). The data was analyzed statistically by applying t-test (Gecer et al., 2016).

\section{Results and Discussion}

\section{Energetic parameters}

The meanvalues of glucose, cholesteroland triglycerides were differed significantly $(\mathrm{P}<0.05)$ between two group males, slightly higher in rut camels (Table 1 ) may be due to the metabolic overactivity. Current study results support the findings of Al-Harbi (2012) who also reported higher values in rutting males and further suggested that these indications could be used for the detection of rutting behavior and condition of male camels. Osman and Al-Busadah (2003) reported elevated lactic-acid contents in camel blood and this may be the reason of increased glucose level in camels which is also supportive of the present results. Alike glucose values were reported by Faye and Bengoumi (2018) as $60-140 \mathrm{mg} / \mathrm{dl}$.

Reported concentration of glucose was $65.55 \pm 3.86$ $\mathrm{mg} / \mathrm{dl}$ in nomadic Sudanese camels (Babeker, 2013). Eltayeb et al. (2015) reported mean glucose concentration as $82.3 \pm 14.1,106.7 \pm 26.6,79.7 \pm 8.2 \mathrm{mg} /$ $\mathrm{d} 1$ respectively in groups with regular water provision, no water for $48 \mathrm{~h}$ and $4 \mathrm{hr}$ after water provision. These results support the present study findings, as glucose concentration was found being increased in stress condition, so it is evident of the fact that in rutting season the animal observes hormonal stress, so due to the reason the blood glucose concentration was found to be elevated.

Table 1: Blood biochemical profile of male Marecha camel $(n=5)$ non-breeding and breeding season.

$\begin{array}{lll}\text { Parameters } & \text { Non-rut (August) } & \text { Rut (February) } \\ \text { Glucose }(\mathrm{mg} / \mathrm{dl}) & 136.68 \pm 5.46^{\mathrm{a}} & 142.62 \pm 4.38^{\mathrm{b}} \\ \text { Cholesterol }(\mathrm{mg} / \mathrm{dl}) & 57.12 \pm 4.44^{\mathrm{a}} & 59.32 \pm 4.26^{\mathrm{b}} \\ \text { Triglycerides }(\mathrm{mg} / \mathrm{dl}) & 35.18 \pm 3.26^{\mathrm{a}} & 36.97 \pm 3.63^{\mathrm{b}} \\ \text { Total Protein }(\mathrm{g} / \mathrm{dl}) & 7.20 \pm 1.48 & 7.08 \pm 1.24 \\ \text { Urea }(\mathrm{mg} / \mathrm{dl}) & 46.28 \pm 2.68 & 45.80 \pm 2.44 \\ \text { Creatinine }(\mathrm{mg} / \mathrm{dl}) & 1.51 \pm 0.07 & 1.49 \pm 0.09 \\ \text { Calcium }(\mathrm{mg} / \mathrm{dl}) & 9.88 \pm 1.16^{\mathrm{a}} & 9.06 \pm 1.18^{\mathrm{b}} \\ \text { Phosphorus }(\mathrm{mg} / \mathrm{dl}) & 4.77 \pm 0.8^{\mathrm{a}} & 4.06 \pm 0.9^{\mathrm{b}}\end{array}$

Means having different superscript in columns are significantly different $(P<0.05)$.

Contrary to current findings, Abdalmula et al. (2019) reported lower values of glucose, cholesterol and triglycerides as $87.83 \pm 9.95,34.81 \pm 2.88$ and $29.41 \pm 2.00 \mathrm{mg} / \mathrm{dl}$ in male camels. Elitok and Cirak (2018) reported glucose and cholesterol concentrations as $114.33 \pm 3.2,22.03 \pm 0.52 ; 108.03 \pm 2.45,21.80 \pm 1.30$; $103.32 \pm 2.76,16.89 \pm 1.34$ and $118.70 \pm 1.25,24.99 \pm 1.88$ $\mathrm{mg} / \mathrm{dl}$ in male dromedary camels in pre-rut, rut, postrut and non-rut season respectively. While creatinine concentrations also varied significantly in their study and these variations from present results may be due to the geographical, breed and nutritional factors.

Hamad et al. (2018) reported glucose, cholesterol and triglycerides concentrations as $6.90 \pm 1.48$, $0.86 \pm 0.41,0.23 \pm 0.1 ; 6.38 \pm 0.87,0.80 \pm 0.11,0.17 \pm 003$; $6.26 \pm 0.26,0.91 \pm 0.05,0.17 \pm 0.03 \mathrm{mmol} / 1$ in winter (January-March), spring (April-June) and summer (July-September) season respectively, in Algerian dromedary male camel.

\section{Protein parameters}

The mean values of total protein, urea and creatinine were found to differ non-significantly in male camels in non-rut and rut season (Table 1). The present study findings are in normal range and support the results of Al-Harbi (2012) while different from the findings of Elitok and Cirak (2018). Reported serum total protein concentration was $7.31 \pm 0.27$ and $7.20 \pm 0.16$ $\mathrm{mg} / \mathrm{dl}$ in dromedary male camel during non-rut and rut season respectively (Al-Harbi, 2012). Elitok and 
Cirak (2018) reported creatinine and blood urea nitrogen concentrations as $1.48 \pm 0.41,30.50 \pm 0.16$; $1.53 \pm 0.47,30.20 \pm 0.22 ; 1.57 \pm 0.65,30.80 \pm 0.19$ and $1.45 \pm 0.66,30.20 \pm 0.14 \mathrm{mg} / \mathrm{dl}$ in male dromedary camels in pre-rut, rut, post-rut and non-rut season, respectively.

According to the results reported by Eltayeb et al. (2015), the mean total protein $(\mathrm{g} / \mathrm{dl})$ and urea, creatinine $(\mathrm{mg} / \mathrm{dl})$ concentrations were $5.1 \pm 0.3$, $27.4 \pm 4.1,1.5 \pm 0.3 ; 6.8 \pm 0.8,36.4 \pm 0.9,2 \pm 0.3 ; 5.3 \pm 0.2$, $28.1 \pm 5.1,1.5 \pm 0.3$ respectively, in groups with regular water provision, no water for $48 \mathrm{~h}$ and $4 \mathrm{hr}$ after water provision. These results are contrary to present study findings, as these concentrations were found to be increased in water deprivation stress condition, but in current study these concentrations were found to be lower in breeding season.

Hamad et al. (2018) reported urea $(\mathrm{mmol} / \mathrm{l})$ and creatinine $(\mu \mathrm{mol} / \mathrm{l})$ concentrations as $10.20 \pm 3.03$, $167.34 \pm 43.7 ; 11.73 \pm 1.93,182.63 \pm 4.12 ; 15.34 \mathrm{~b} \pm 0.69$, $181.83 \pm 7.27$ in winter (January-March), spring (April-June) and summer (July-September) season respectively, in Algerian dromedary male camel. Reported values of total protein and urea were to be $8.2 \mathrm{~g} / \mathrm{dl}$ and $25.04 \mathrm{mg} / \mathrm{dl}$ in Bangladeshi dromedary camels (Islam et al., 2019).

\section{Minerals}

The mean values of calcium and phosphorus were found to be differed significantly $(\mathrm{P}<0.05)$ as higher in non-rutting males (Table 1). Moreover, it has been documented that mineral levels have been found elevated in rutting and green season (AlHarbi, 2012). Calcium metabolism is related to hormonal regulations of thyroid and parathyroid which becomes more active in stressed condition (E1Khasmi et al., 2000). In dromedaries, an increase was found in calcium and phosphorus concentrations in wet season due to the availability of plants richer in minerals (Amin et al., 2007), this also confirms the current results as the availability of feeding is same to non-rutting and rutting males, but the rutting animals showed decreased calcium and phosphorus values may be due to hormonal stress condition.

Other authors recorded an increase in calcium but decrease in phosphorus concentrations in summer season (E1-Harairy et al., 2010). Reported concentrations of calcium were $11.61 \pm 0.70 \mathrm{mg} / 1$ in Sudanese nomadic camels (Babeker, 2013). Contrary to this, in female camels, Elitok and Cirak (2018) reported calcium and phosphorus mean concentrations as $9.0 \pm 0.1$ and $3.8 \pm 0.5 \mathrm{mg} / \mathrm{dl}$, while $2.22 \pm 0.08$ and $1.70 \pm 0.11 \mathrm{mmol} / 1$ in Egyptian shecamel (Ebissy et al., 2019).

\section{Conclusions and Recommendations}

Blood biochemicals study provides ample information about health condition and physiological stress generally. The elevated levels of serum biochemicals like glucose, cholesterol and triglycerides in response to rutting condition affect the general physiological state and functions including sexual performance. This increase may be attributed to metabolic state overactivity or hormonal stress and these parameters could be used to detect rutting male.

\section{Acknowledgements}

The support of CBRS is gratefully acknowledged.

\section{Novelty Statement}

Camel put an indispensible role in economy of marginal areas, but still it is ignored in Pakistan. So, an initiative is taken to illustrate different parameters of camel husbandry under natural milieus. Present study is the series of same which will plot footprints to develop database line for pastoral community.

\section{Author's Contribution}

\section{Asim Faraz and Muhammad Shahid Nabeel:} Conducted research and write-up.

Abdul Waheed and Nasir Ali Tauqir: Helped in analysis and review.

\section{Conflict of interest}

The authors have declared no conflict of interest.

\section{References}

Abdalmula, A.M., F.M. Benashour, M.E. Shmela, F.A. Alnagar, I.M. Abograra and A.O. Buker. 2019. Blood profile in normal one humped dromedary (Camelus dromedarius) camels in Libya. Part 3: Effect of sex variation on biochemical and hematological blood profile. 
Int. J. Sci.: Basic Appl. Res. 48: 9-24.

Aichouni, A., M. Belhadia, N. Kebir and H. Aggad. 2013. Season influence on serum organic parameters of dromedarius (Camelus dromaderius) in Algeria. Biochem. Biotechnol. Res., 1: 8-12.

Al-Harbi, M.S., 2012. Some hematological values and serum biochemical parameters in male camels (Camelus dromedaries) before and during rut. Asian J. Anim. Vet. Adv., 7: 1219-1226. https://doi.org/10.3923/ ajava.2012.1219.1226

Amin, A.S.A., K.A. Abdoun and A.M. Abdelatif. 2007. Seasonal variation in blood constituents of one-humped camel (Camelus dromedarius). Pak. J. Biol. Sci., 10: 1250-1256. https://doi. org/10.3923/pjbs.2007.1250.1256

Babeker, E.A., 2013. Observation of certain hematological and biochemical parameters in nomadic camels (Camelus dromedarius) in the Sudan. Univ. Bakht Alruda Scient. J. 6: 167174.

Ebissy, E.A., A.A. El-Sayed and R.H. Mohamed. 2019. Hematological and biochemical profile in female camels (Camelus dromedarius) during the transition period. Slov. Vet. Res., 56: 571577. https://doi.org/10.26873/SVR-794-2019

El-Harairy, M., A. Zeidan, A. Afify, H. Amer and A. Amer. 2010. Ovarian activity, biochemical changes and histological status of the dromedary she-camel as affected by different seasons of the year. Nat. Sci., 8: 54-65.

Elitok, B. and A.C. Cirak. 2018. Clinical, hematological and blood biochemical features of camel. MOJ Immunol., 6: 288-295.

El-Khasmi, M., F. Riad, A. Safwate, M. Bengoumi, K. Hidane, M.J. Davicco, V. Coxam, B. Faye, J.P. Barlet. 2000. Evolution compare de quelques paramètres minéraux, de l'ostéocalcine, du $25(\mathrm{OH}) \mathrm{D}$ et du 1,25(OH)2D chez la chamelle du Sud marocain et son chamelon nouveau-né. Rev Elev Méd Vét Pays Trop., 53(2): 115-119. https://doi.org/10.19182/remvt.9732

Eltayeb, R., H. Osman and E. Babiker. 2015. The effect of water deprivation on blood constituents of the dromedary camel (Camelus dromedarius). Am. Sci. Res. J. Eng. Technol. Sci., 14: 258-264.

Faraz, A., A. Waheed, R.H. Mirza and H.M. Ishaq. 2019a. The camel a short communication on classification and attributes. J. Fish. Livest.
Prod., 7: 289.

Faraz, A., A. Waheed, R.H. Mirza and H.M. Ishaq. 2019c. Role of camel in food security: A perspective aspect. J. Fish. Livest. Prod., 7: 290.

Faraz, A., A. Waheed, R.H. Mirza, H.M. Ishaq and M.M. Tariq. 2019b. Socio economic status and associated constraints of camel production in desert Thal Punjab, Pakistan. J. Fish. Livest. Prod., 7: 288.

Faraz,A.,M.Younas,M.Lateef and G.Muhammad. 2018. Effect of intensive and semi-intensive management systems on growth performance and economics of Marecha (Camelus dromedarius) calves reared under desert conditions. Pak. J. Agric. Sci., 55: 625-632. https://doi.org/10.21162/PAKJAS/18.4631

Faraz, A., 2020. Food security and socio-economic uplift of camel herders in Southern Punjab, Pakistan. Land Sci., 2(2): 8-11. https://doi. org/10.30560/1s.v2n2p8

Faraz, A., 2021. Blood biochemical and hair mineral profile of camel calves reared under different management systems. Pak. J. Zool., 53(1): 55-61. https://doi.org/10.17582/journal. pjz/20190430140425

Faraz, A., A. Waheed, A.B. Mustafa, N.A. Tauqir, R.H. Mirza, H.M. Ishaq, R.M. Bilal and M.S. Nabeel. 2021. Milk production potential of Marecha camel (Camelus dromedarius) in extensive and semi-intensive management systems. Pak. J. Zool., 53(1): 273-280. https:// doi.org/10.17582/journal.pjz/20200227090212

Faye, B. and M. Bengoumi. 2018. Camel Clinical Biochemistry and Hematology. Cham: Springer, ISBN: 978-3-319-95560-5. https:// doi.org/10.1007/978-3-319-95562-9

Faye, B., 2014. The camel today: Assets and potentials. Anthropozoologica, 49: 167-176. https://doi.org/10.5252/az2014n2a01

Gecer, M.K., M. Akin, M. Gundogdu, S.P. Eyduran, S. Ercisli and E. Eyduran. 2016. Organic acids, sugars, phenolic compounds, and some horticultural characteristics of black and white mulberry accessions from Eastern Anatolia. Can. J. Plant Sci., 96: 27-33. https:// doi.org/10.1139/cjps-2015-0070

Hamad, B., H. Aggad, L. Hadef and A. Adaika. 2018. Effect of seasons on blood biochemical parameters in male dromedary camels in Algeria. Indian J. Anim. Res., 52: 678-682. https://doi.org/10.18805/ijar.v0iOF.9165 
Islam, S., J. Ferdous, M.K. Rahman, S. Akhtar, M.M. Hassan and A. Islam. 2019. Reference values for hematological and serum biochemical parameters of dromedary camel (Camelus dromedarius) in sub-tropical climate of Bangladesh. Adv. Anim. Vet. Sci., 7: 232-237. https://doi.org/10.17582/journal. aavs/2019/7.4.232.237

Kadim, I.T., 2013. A review of the nutritive value and meat quality characteristics of the dromedary (Camelus dromedaries) camel meats. Camel Int. J. Vet. Sci., 1: 129-156. https://doi.org/10.5958/j.2321-709X.2.1.003

Marai, I.F.M., A.E.B. Zeidan, A.M. AbdelSamee, A. Abizaid and A. Fadiel. 2009. Camels reproductive and physiological performance traits as affected by environmental conditions. Trop. Subtrop. Agroecosyst. 10: 129-149.

Momenah, M.A., 2014. Some blood parameters of one humped she camels (Camelus dromedaries) in response to parasitic infection. Life Sci.J., 11: 118- 123.

Osman, F.A., H.I. Gaadee and G.A. Sayed. 2015. Clinico-hematological and biochemical changes in camels infected with gastro intestinal parasites. J. Anim. Sci. Adv., 5: 1245-1252. https://doi.org/10.5455/jasa.20150425041450

Osman,T.E.A. and K.A.Al-Busadah.2003. Normal concentrations of twenty serum biochemical parameters of She-camels, Cows and Ewes in Saudi Arabia. Pak. J. Biol. Sci., 6: 1253-1256. https://doi.org/10.3923/pjbs.2003.1253.1256

Tibary, A. and A. Anouassi. 1997. Theriogenology in Camelidae. $1^{\text {st }}$ Edn., Ministry of Agriculture and Information, United Arab Emirates.

Yagil, R. and Z. Etzion. 1980. Hormonal and behavioral patterns in the male camels (Camelus dromedarius). J. Reprod. Fertil., 58: 61-65. https://doi.org/10.1530/jrf.0.0580061 